\title{
Differences in diet between the two largest breeding colonies of Audouin's gulls: the effects of fishery activities*
}

\author{
VITTORIO PEDROCCHI ${ }^{1}$, DANIEL ORO ${ }^{1,2 \dagger}$, JACOB GONZÁLEZ-SOLÍS ${ }^{1}$, \\ XAVIER RUIZ ${ }^{1}$ and LLUÍS JOVER ${ }^{3}$
}

\begin{abstract}
${ }^{1}$ Dept. Biologia Animal, Facultat de Biologia, Universitat de Barcelona, Av. Diagonal 645, 08028 Barcelona, Spain. ${ }^{2}$ Present address: Institut Mediterrani d'Estudis Avançats IMEDEA (CSIC-UIB), Miquel Marques 21, 07190 Esporles, Mallorca, Spain. E-mail: d.oro@uib.es

${ }^{3}$ Dept. de Salut Pública i L.S (Bioestadística). Facultat de Medicina, Universitat de Barcelona, C/ Casanova 143, 08036 Barcelona, Spain
\end{abstract}

\begin{abstract}
SUMMARY: We analysed and compared the diet of Audouin's gulls Larus audouinii between their two largest breeding sites in the world: the Ebro Delta and the Chafarinas Islands (western Mediterranean). These two localities showed marked differences in the features of the commercial fishing fleet: in the Ebro Delta area a large fishing fleet produced large amounts of discards, while in the Chafarinas the fleet discarded smaller amounts of fish and marine invertebrates, due to the smaller number of vessels. It is also likely that the percentage of discards from total catches is also lower around the Chafarinas than at the Ebro Delta. We distinguished two types of fishing to compare diet compositions: diurnal (only trawling activity) and diurnal and nocturnal (trawling and purse-seine activity, respectively). We also differentiated regurgitates from young nestlings (up to 20 days old) and from older nestlings or adult birds. At the two localities, fish was the main food of Audouin's gulls, with epipelagic prey (mainly clupeoids) being more important when both diurnal and nocturnal fisheries were operating. This confirms that epipelagic prey either caught actively by the gulls or linked to fisheries was particularly important in the feeding habits of Audouin's gulls. Nevertheless, differences between the two colonies appear mainly when only trawlers operated: while at the Ebro Delta gulls showed higher consumption of benthic-mesopelagic prey (probably linked to a higher trawler discard availability), gulls from the Chafarinas Islands consumed higher biomass of epipelagic prey probably caught actively at night. When both fleets operated around the two colonies, the average biomass of prey in a regurgitate of younger chicks was significantly higher at the Ebro Delta than at Chafarinas, and the opposite trend was recorded for older nestlings and adults. Niche width was broader in Chafarinas than in the Ebro Delta for both age classes and for any fishing fleet schedule, suggesting again that the exploitation of discards was higher at the Ebro Delta than at the Chafarinas, where gulls showed a more varied diet. Despite the fact that availability of discards was probably higher at the Ebro Delta than at Chafarinas, the per capita availability was not so different at both localities due to the increasing seabird community population at the Ebro Delta, which ca. doubled that at Chafarinas in the last decade.
\end{abstract}

Key words: Larus audouinii, fishery discards, abundance, diet composition.

RESUMEN: DifERENCIAS EN LA DIETA ENTRE LAS DOS MAYORES COLONIAS DEL MUNDO DE GAVIOTA DE AUdOUIN: EFECTOS DE LAS ACTIVIDADES PESQUERAS. - En el presente trabajo analizamos y comparamos la dieta de la gaviota de Audouin Larus audouinii entre sus dos colonias de cría más grandes del mundo: la del delta del Ebro y la de las islas Chafarinas (Mediterráneo occidental). Las dos localidades mostraron diferencias marcadas en las características de la flota pesquera comercial: en el delta del Ebro una flota muy importante genera grandes cantidades de descartes, mientras que en las Chafarinas la flota local descarta cantidades menores de peces e invertebrados marinos, debido al reducido número de barcos que allí faenan.

$\dagger$ Corresponding author.

*Received March 23, 2001. Accepted December 19, 2001. 
Es también probable que el porcentaje de descarte respecto a la captura total sea menor en las Chafarinas que en el delta del Ebro. Para la comparación de la dieta distinguimos entre dos tipos de regimenes de pesca: diurno (sólo actividad de los arrastreros) y diurna y nocturna (actividad de arrastre y de cerco respectivamente). También distinguimos entre regurgitados de jóvenes pollos (hasta los 20 días de edad) y volantones y adultos. En las dos localidades, los peces fueron el principal alimento de la gaviotas de Audouin, siendo las presas epipelágicas (fundamentalmente los clupeidos) más importantes cuando las dos flotas de arrastre y cerco faenaban. Este resultado confirma que las presas epipelágicas capturadas activamente por las gaviotas o bien gracias a la actividad pesquera son particularmente importantes en los hábitos tróficos de la especie. No obstante, las diferencias entre las dos colonias aparecen principalmente cuando sólo faenan los arrastreros: mientras en el delta del Ebro las gaviotas mostraron un consumo superior de presas bentónicas o mesopelágicas (seguramente ligadas a una mayor tasa de descartes de arrastre), las gaviotas de Chafarinas consumieron cantidades de biomasa mayores de presas epipelágicas, probablemente capturadas activamente durante la noche. Cuando ambas flotas faenaron alrededor de las dos colonias, la biomasa promedio por regurgitado en los pequeños pollos fue significativamente mayor en el Delta que en Chafarinas, mientras que la tendencia opuesta se registró para volantones y adultos. La amplitud de nicho trófico fue mayor en Chafarinas que en el delta del Ebro para ambas clases de edad y para cualquier régimen de pesquerías, sugiriendo una vez más que la explotación de los descartes pesqueros fue mayor en el Delta del Ebro que en Chafarinas, donde las gaviotas mostraron una dieta más variada. A pesar de que la disponibilidad de descartes fue mayor en el delta del Ebro que en Chafarinas, la disponibilidad per capita no fue tan diferente debido al aumento en el número de parejas reproductoras de la comunidad de aves marinas del Delta, que ha casi doblado la de Chafarinas en la última década.

Palabras clave: abundancia, composición de la dieta, descartes pesqueros, Larus audouinii.

\section{INTRODUCTION}

Audouin's gull Larus audouinii is considered a specialist in the capture of clupeiforms during the night (see Oro 1998 and references therein), though it is now well known that the species also scavenges at nocturnal and diurnal commercial fisheries (e.g. González-Solís et al., 1997a; Oro et al., 1997; Oro and Ruiz, 1997). However, this opportunistic behaviour seems to be more widespread in the western than in central and eastern Mediterranean breeding areas (Oro, 1998), where colonies are mainly located in areas with lower fishing activity (e.g. GFCM, 1967 and 1991; Oro, 1998).

The increase of the world population of Audouin's gull has been dramatic in the last 15 years, and its growth rate is one of the largest ever recorded for a larid species. Most of this increase occurred at a new colony established in the Ebro Delta in 1981, which currently holds $60 \%$ of the total world population (Oro, 1998). The high availability of discards from trawler fishing boats has probably enhanced the growth of this colony (Oro and Ruxton, 2001), as suggested in other studies of scavenging seabird species (e.g. Furness et al., 1992). The second largest colony of Audouin's gulls in the world is at the Chafarinas Islands, which holds ca. $25 \%$ of total population.

Several studies have recorded the feeding habits of Audouin's gulls. However, fecal pellets have been used as the main source of information (de Juana et al., 1979; Witt, 1977a; Witt et al., 1981), or information coming from different food sampling methods has been merged (Català et al., 1990; Ruiz et al., 1996). Most of the available information has not paid attention to the age of sampled individuals, and has relied on small sample sizes (e.g. Wallace, 1969; Mester, 1971; Araujo et al., 1977; Witt, 1977b; Beaubrun, 1983).

In this study we compared the diet of different age groups of Audouin's gulls at the Ebro Delta and at the Chafarinas, according to the activity of local commercial fisheries. We performed diet comparisons on the basis of information provided from regurgitates, which is the least biased means of food sampling used to describe the diet of gulls during the breeding season (Pedrocchi et al., 1996; GonzálezSolís et al., 1997b).

\section{METHODS}

\section{Study areas and fisheries}

The Ebro Delta $\left(40^{\circ} 40^{\prime} \mathrm{N}, 0^{\circ} 45^{\prime} \mathrm{E}\right.$; W Mediterranean) colony is located in the Peninsula de la Banya, a protected area formed by 2500 ha. of salt marshes. This area is an important fishing ground of the Mediterranean (Palomera, 1992; Palomera and Pertierra, 1993), resulting in one of the largest fishing fleets in this region (Irazola et al., 1996; Oro 1999): ca. 170 trawlers, operating only by day and ca. 50 purse-seine vessels, operating only by night. The Chafarinas $\left(35^{\circ} 11^{\prime} \mathrm{N}, 2^{\circ} 26^{\prime} \mathrm{W}\right.$; SW Mediterranean) are a small volcanic archipelago $3.5 \mathrm{~km}$ off the Moroccan coast. About 50 trawlers from Nador harbour (50 km west of the colony) and 13 purse-seine vessels from Ras el Ma harbour (just off the islands) operate around the islands, the former operating continuously, night and day, and 
the later only by night (e.g. González-Solís et al., 1997a, 1998). The distance between the two colonies is ca. $650 \mathrm{~km}$.

To assess possible differences in fish availability from fishing fleets around the two colonies, we used two rough approaches: first, we assumed that fish discarded from trawlers was proportional to the catches landed (e.g. Oro and Ruiz, 1997) (for this we only had available the total catches from the Ebro Delta area and we assumed that proportion of fish discarded at the two areas was not different using simply the number of vessels at the two areas to estimate fish discarded); and second, estimates of fish landed from purse-seine activities using catch statistics in every area from fishermen bulletins.

\section{Food samples}

Fresh regurgitates from adults and nestlings were collected during the breeding seasons (May-June) of 1993, 1994 and 1995. Adult regurgitates were collected while birds were incubating so this food was not intended for feeding chicks. The fishing activity around the colony when regurgitates were collected was recorded to assign samples to different fishing activity categories (see below). Where possible, prey items were identified to the species level using reference collections of fish and invertebrates. Dry weights were obtained either directly by desiccation in an oven at $60^{\circ} \mathrm{C}$, or through the application of linear regression predictions of dry weight biomass from available measures (Rogers et al., 1977; Díaz and Díaz, 1990; our data).

We included in the analysis only those regurgitates collected during comparable fishing situations in both areas. Daily statistical catches were available from Ras-el-Ma, the closest harbour to the Chafarinas colony. These data allowed us to distinguish between two fishing situations: 1) days with both diurnal (trawlers) and nocturnal (purseseine) fishing and 2) days with diurnal fishing only (see also González-Solís et al., 1997a and 1998). At the Ebro Delta there were four situations: both diurnal and nocturnal fishing activities, only diurnal, only nocturnal, and none (e.g. Oro, 1995; Oro and Ruiz, 1997). From these, two were discarded (only nocturnal and none) because they were less comparable with the situations found in Chafarinas, as indicated by an analysis of correspondence on the typological categorisation of prey items (Fig. 1). In this analysis, all the fishing situations and typologies were represented in a bidimension-

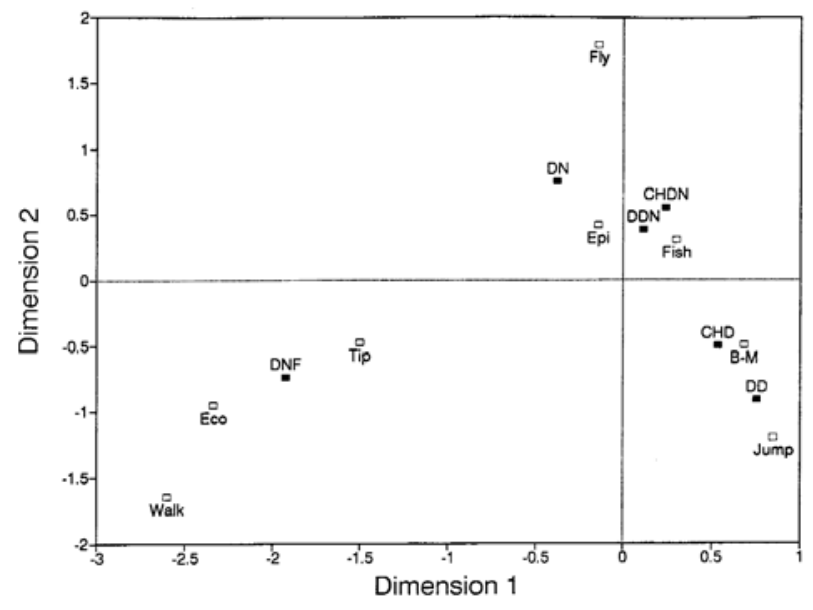

FIG. 1. - Simple correspondence analysis for all the fishing situations and colonies at typological level. DN = 'Delta nocturnal'; $\mathrm{DNF}=$ 'Delta no fishing'; DDN = 'Delta diurnal and nocturnal'; $\mathrm{DD}=$ 'Delta diurnal'; CHDN = 'Chafarinas diurnal and nocturnal fishing'; CHD = 'Chafarinas diurnal'. Typologies: Walk = Terrestrial walker; Eco = Ecotonic; Tip = Garbage; Epi = Epipelagic; Fly = Flying; Fish = Indeterminated Fish; B-M = Benthic-Mesopelagic; Jump = Jumper.

al graph following the axis of maximum inertia, which explains their similarity with a cumulative $83 \%$ of variability.

We distinguished between two age classes: chicks younger than 20 days, and gulls older than 21 days. Age of chicks was assessed using bill and tarsus measures and applying chick growth curves previously calculated at the two colonies (authors, unpubl. data). We assumed that diets of older nestlings and adults did not differ significantly, as indicated by previous studies (e.g. Pedrocchi et al., 1996).

\section{Diet analysis}

Prey items were grouped according to taxonomic and typologic categories (Cooper et al., 1990). To describe the importance of each category we used the number of prey items $(\mathrm{N})$ belonging to it, the percentage by number it represented $(\% \mathrm{~N})$, its percentage of occurrence $(\% \mathrm{P})$, and the percent of biomass (\%B). Niche width was estimated using Brillouin's diversity index (Pielou, 1975) combined with a Jack-knife procedure to obtain associated variances (Zahl, 1977) and a modified Student t-test for comparisons (Hutcheson, 1970).

Dietary differences have been assessed using the $\mathrm{G}$ test (likelihood ratio) on contingency tables (Zar, 1984). Biomass values were compared using MannWhitney U tests. 
TABLE 1. - Descriptors of the diet of Audouin's gull during May-June 1993, 1994 and 1995 relative to colony and age of the individuals when diurnal and nocturnal fisheries operated, at both taxonomic and typologic levels. Diversity indices are also shown at both levels $(\% \mathrm{~N}=$ numeric percentage, $\% \mathrm{P}=$ percentage of occurrence, $\% \mathrm{~B}=$ biomass percentage).



\section{RESULTS}

Taxonomic and typologic diet composition according to fishing situations for both localities is described in Tables 1 and 2. Overall, Audouin's gulls fed mostly on Clupeiforms and Perciforms. The most frequently consumed clupeiform in the Ebro Delta was the Sardine, Sardina pilchardus, whereas in Chafarinas it was the Gilt sardine, Sardinella aurita. The Anchovy, Engraulis encrasicolus, which appeared in both localities, was less important.

Secondary prey from foraging habitats other than the sea were very scarce. Such prey were caught in ecotonic habitats, like rice fields in the Ebro Delta (such as leeches Hirudo medicinalis or eels Anguilla anguilla), or crops in the Moroccan coast (such as grasshoppers).

We found distinctive prey types associated with the fishing activities, an increased proportion of benthic-mesopelagic prey appeared when only trawlers operated, whereas epipelagic prey appeared especially when diurnal and nocturnal fisheries operated at the same time (Table 1). Fish availability for the two colonies, according to different fishing activities, is shown in Figure 2.

\section{Diurnal and nocturnal fishing}

For the younger age class, there are significant differences in diet composition between the localities, both at taxonomic and typologic level (G-test $=$ 22.57, $\mathrm{p}=0.0001$ for taxonomic categories, $\mathrm{G}=$ $18.76, \mathrm{p}<0.001$ for typologic categories) but not for the older age class $(\mathrm{G}=4.96, \mathrm{p}=0.189$ for taxonomic categories, exact $\mathrm{G}=6.35, \mathrm{p}=0.13$ for typologic categories).

We considered the biomass contributed by the different prey categories in the regurgitate of the younger age class. There were no significant differences between localities either for epipelagic $(\mathrm{U}=$ 224.5, $\mathrm{p}=0.14)$, benthic-mesopelagic $(\mathrm{U}=292.5, \mathrm{p}$ $=0.74)$ nor accessory $(\mathrm{U}=292.0, \mathrm{p}=0.69)$ preys. However, the average biomass of prey in a regurgitate was significantly higher at the Ebro Delta $(\mathrm{U}=$ 156.0, $\mathrm{p}<0.01)$. 
TABLE 2. - Descriptors of the diet of Audouin's gull during May-June 1993, 1994 and 1995 relative to colony and age of the individuals when only diurnal fisheries operated, at both taxonomic and typologic levels. Diversity indices are also shown at both levels $(\% \mathrm{~N}=$ numeric percentage, $\% \mathrm{P}=$ percentage of occurrence and $\% \mathrm{~B}=$ biomass percentage)

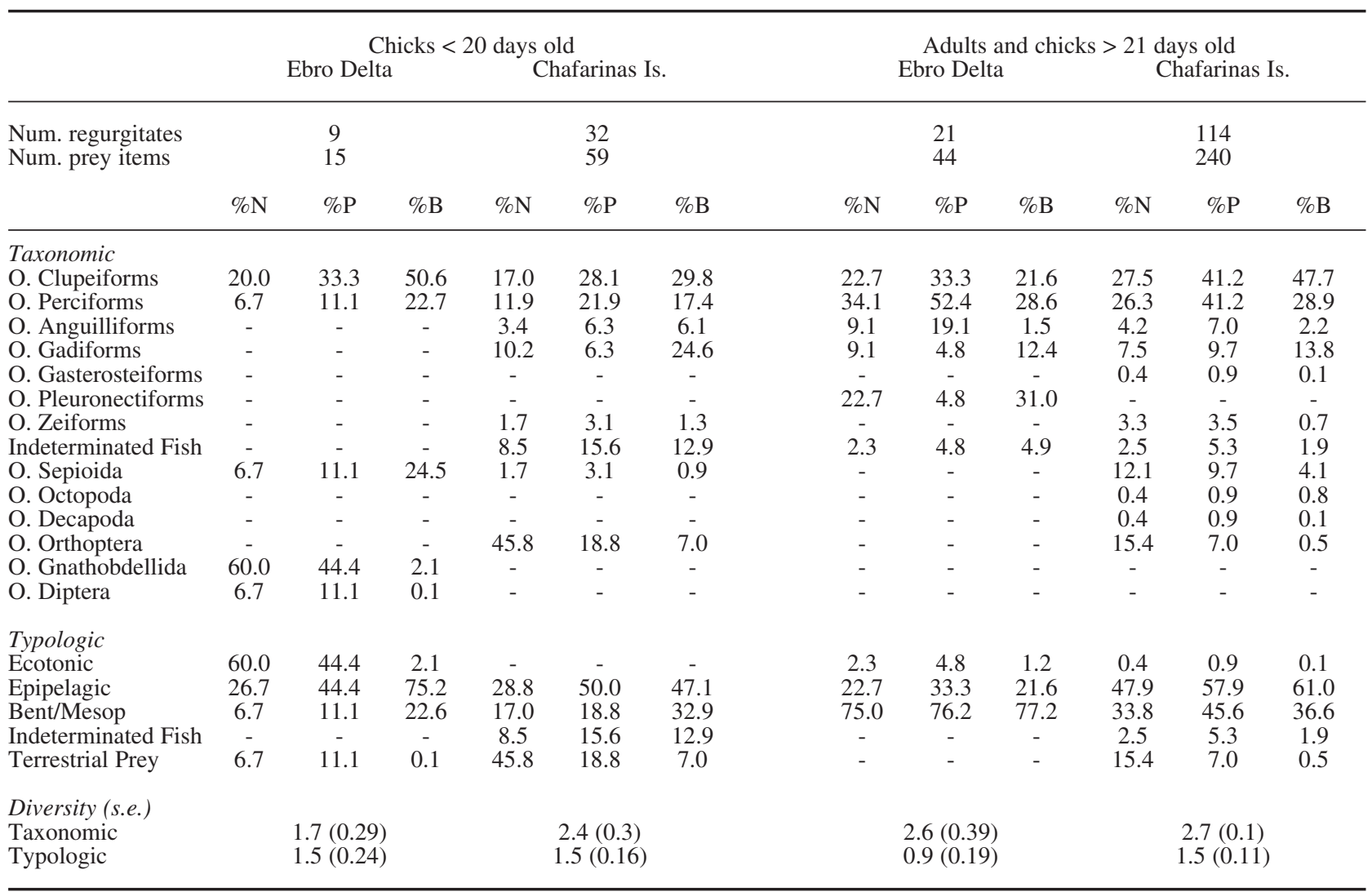
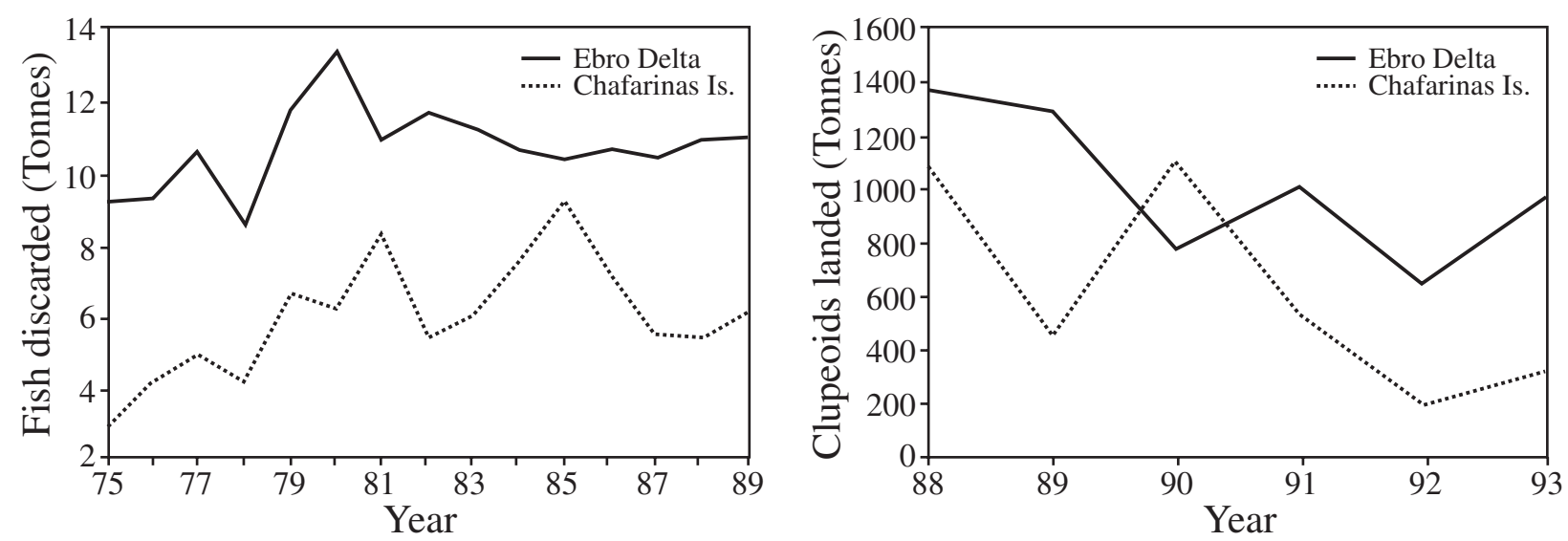

FIG. 2. - Fish availability estimated for every year in the two colonies as the amount of discarded fish from trawling fishing (period 19751989) and from fish landed from purse-seine fishing (period 1988-1993).

The opposite was found for the older age class. The amount of biomass in a regurgitate was significantly higher at Chafarinas than at the Ebro Delta (U $=1942.5, \mathrm{p}=0.01)$, owing to a significantly larger proportion of epipelagic prey items $(\mathrm{U}=2067.0, \mathrm{p}<$ $0.05)$. It was not due to differences in benthicmesopelagic $(\mathrm{U}=2540, \mathrm{p}=0.76)$ nor secondary $(\mathrm{U}$ $=2521.5, \mathrm{p}=0.37)$ prey items.
Niche width according to taxonomic categorisation was significantly broader in Chafarinas than in the Ebro Delta for both age classes (younger chicks, $\mathrm{t}=$ 4.06, $\mathrm{df}=89, \mathrm{p}<0.05$; older chicks and adults, $\mathrm{t}=$ $2.40, \mathrm{df}=125, \mathrm{p}<0.05)$. However, there were no significant differences according to typological categorization (younger chicks, $\mathrm{t}=-0.73, \mathrm{df}=27, \mathrm{p}=0.50$; older chicks and adults, $\mathrm{t}=-1.26$, $\mathrm{df}=115, \mathrm{p}=0.25$ ). 


\section{Diurnal fishing}

In this fishing situation, the epipelagic prey decreased markedly in both localities and were replaced by other prey types mainly belonging to the benthic-mesopelagic category. This led to significant differences in diet composition between the two localities for both age classes and any of the two prey categorisation schemes: younger chicks, $\mathrm{G}=$ 16.42, $\mathrm{p}<0.0005$ (taxonomic categories), $\mathrm{G}=$ $18.73, \mathrm{p}<0.0001$ (typologic categories); older chicks and adults, $\mathrm{G}=33.74, \mathrm{p}<0.0001$ (taxonomic categories), $\mathrm{G}=32.00, \mathrm{p}<0.0001$ (typologic categories).

Trophic diversity was always higher at Chafarinas, but differences were significant only for the older age class in typologic categories $(\mathrm{t}=-2.73$, df $=77, \mathrm{p}<0.05)$.

\section{DISCUSSION}

Audouin's gulls feed mainly on epipelagic fish, provided either by nocturnal fisheries or caught actively by themselves (Witt et al., 1981; Oro, 1998), or on benthic-mesopelagic fish obtained from trawler discards. Our results suggest that the relative importance of these two resources in the diet varied depending heavily on the type of fishing activity and also on the locality. Fishing fleet features at each locality are different, numbers of trawlers being much higher at the Ebro Delta than at the Chafarinas area (e.g. Charbonnier and Garcia, 1985; CGPM, 1988; Demestre et al., 1988; Irazola et al., 1996; own data). In addition, trawling activity and timetable are constant and predictable in space and time around the Ebro Delta (Castilla and Jiménez, 1995; Oro, 1995; Oro and Ruiz, 1997; Oro, 1999), whereas at the Chafarinas the activity pattern of trawlers seemed much less predictable (own data). Furthermore, trawlers generate large amounts of discards because their fishing gears are not selective (Oro and Ruiz, 1997; Oro, 1999), whereas purse-seine boats are highly selective and do not normally discard fish (Arcos and Oro, 2002). Finally purse-seine boats do not always succeed in their search for fish, they may fish for more than one night and their fishing grounds vary in space depending on the season, sea conditions and lunar cycles (Arcos and Oro, 2002). As a consequence, at the Ebro Delta the amount of discards available from trawlers is high and constitutes the main food of breeding gulls (Oro et al., 1996a; Oro and Ruiz, 1997; Oro 1999), whereas at the Chafarinas, gulls caught higher amounts of epipelagic fish especially when purse-seine boats were also operating (González-Solís et al., 1998). Epipelagic fish remained the main resource used by breeding gulls in this locality and this is the cause of the significant dietary differences between the two colonies. When both fishing fleets operated, there were no differences because of the predominance of epipelagic prey in both localities. However, the average biomass of prey in a regurgitate of younger chicks was higher at the Ebro Delta than at Chafarinas, and the opposite trend was recorded for older nestlings and adults. Results suggest that at least part of the clupeiforms consumed by gulls were caught taking advantage of the activity of the purseseine boats, which attract epipelagic fish to the surface using lights, and making them easily accessible to the gulls (Arcos and Oro, 2002). Niche width was broader in Chafarinas than in the Ebro Delta for both age classes and for any fishing fleet schedule, suggesting again that the exploitation of discards was higher at the Ebro Delta than at the Chafarinas, where gulls show a more diverse diet.

We have found specific dietary components linked to age class. Irrespective of the fishing situation, in the younger age class epipelagic prey predominated in the diets of the Ebro Delta vs. Chafarinas, while the proportion of benthic-mesopelagic prey was always significantly more important at Chafarinas in every fishing situation. Furthermore, younger chicks had a distinct dietary component of small soft-bodied prey, which were caught for them by adults in non-marine environments both at the Ebro Delta (rice fields) and at the Chafarinas (terrestrial grounds) colonies. This has been interpreted as a way to overcome problems posed by hyperosmotic marine prey to younger seabird chicks (Ricklefs et al., 1978). Other studies have reported this kind of prey in the food composition of young gulls (Spaans, 1971; Mudge and Ferns, 1982; Fox et al., 1990; Hillström et al., 1994).

The rough estimates of the amounts of fish discarded or made accessible by human fisheries suggest that they are probably higher at the Ebro Delta than at the Chafarinas. Although information available from purse-seine fisheries suggest that differences in activity of this fleet between the two areas are not large, purse-seine fisheries do not generate large amounts of discards and are probably a resource less important than trawler discards (see 
also Arcos and Oro, 2002). Very little is known about the rate of discarded fish by trawlers along the Moroccan Mediterranean coasts, though the difference in number of trawlers operating around the two colonies is large. However, it seems that Moroccan vessels probably discard less fish than Spanish vessels due to the differences in fish market features between the two countries. For instance, some common species caught by trawlers like bogue Boops boops or Mediterranean horse mackerel Trachurus mediterraneus are normally discarded at the Ebro Delta area while around the Chafarinas islands they are landed for sale (authors pers. obs.). The importance of the fishing fleet around the Ebro Delta is not casual, but due to the importance of the fishing grounds in the area, which are in turn the result of several oceanographic features (high width of the continental shelf, nutrients carried by the Ebro river) that enhance primary production (e.g. Salat, 1996; Estrada, 1996). It is known that in this area large concentrations of seabirds occur (both scavenging seabirds and seabirds that scavenge only occasionally), some of them coming from distant breeding colonies (e.g. Abelló and Oro, 1998; Arcos and Abelló, unpubl. data). This means that even when trawlers do not operate (such as during trawling moratoria), gulls breeding at the Ebro Delta can still exploit the high availability of fish (mainly clupeoids) around the colony (e.g. Oro et al., 1996a, b). At the Chafarinas Islands oceanographic features seem different, with narrow continental shelf and primary production very variable depending on the entries of cold water from the Atlantic Ocean through the Gibraltar Strait (e.g. Rubin, 1997; Font et al., 1998). These facts probably explain why breeding success of Audouin's gulls has been normally higher at the Delta, especially before the establishment of a trawling moratorium from 1991 that overlaps with the breeding season of the gulls (e.g. Oro et al., 1996a, b; Oro, 1998). Some data also suggest that density dependent food availability may operate at the Chafarinas but not at the Ebro Delta colony (Ruiz et al., 1998 and Oro, 1999 respectively), where the energy available for the seabird community is still higher than the energy required (Oro 1999). However, the per capita availability of trawler discards at the two colonies is probably not very different, due to the increasing breeding seabird community at the Ebro Delta, which in the last decade is much larger than that at the Chafarinas (ca. 20000 and 8000 pairs respectively).

\section{ACKNOWLEDGEMENTS}

We thank Meritxell Genovart, Joan Carles Abella, and members of GENA and ICONA for helping in the fieldwork. Robin Rycroft from SAL and Diana Bowler improved the English text. We are also grateful to Bob Furness, Bill Montevecchi, Mark Tasker, Pere Abelló and an anonymous referee for improving drafts of the manuscript. Authorities of the Ebro Delta Natural Park gave us logistic support. Research funds were provided by the ICONA (Instituto para la Conservación de la Naturaleza) and DGICYT grant PB91-0271 of the Spanish Government.

\section{REFERENCES}

Abelló, P. and D. Oro. - 1998. Offshore distribution and assemblages of breeding seabirds in the Catalano-Balearic Sea (northwestern Mediterranean). Col. Waterbirds, 21: 422-426.

Araujo, J., J. Muñoz-Cobo and F.J. Purroy. - 1977. Las rapaces y aves marinas del archipiélago de Cabrera. Naturalia Hispanica, 12: 79-86.

Arcos, J.M. and D. Oro. - 2002. The role of nocturnal purse-seiners as a feeding resource for seabirds in the Ebro Delta area (NW Mediterranean). Mar. Biol., 141 (in press)..

Beaubrun, P-C. - 1983. Le Goéland d'Audouin (Larus audouinii Payr.) sur les cotes du Maroc. L'oiseau et Revue Française d' Ornithologie, 53: 209-226.

Castilla, A. and J. Jiménez. - 1995. Relationships between fishery activities and presence of the Audouin's gull (Larus audouinii) in the Columbretes islands. Col. Waterbirds, 18: 108-112.

Català, F.J., M. Verdú and F.J. García. - 1990. Contribución al estudio de la ecología trófica de Larus audouinii y Larus cachinnans michaellis en las islas Columbretes. Medi Natural, 2: $97-102$.

CGPM. - 1988. Rapport de la V Consultation technique du Conseil general des pêches pour la Mediterranée sur l'évaluation des stocks dans les divisions statistiques Baléares et golfe du Lion. FAO Rapp. Pêches, 395: 190 pp.

Charbonnier, D. and S. Garcia. - 1985. Atlas of the fisheries of the western and central Mediterranean. FAO-CGPM / CEE, 78 pp.

Cooper, R.J., P.J. Martinat and R.C. Whitemore - 1990. Dietary similarity among insectivorous birds: Influence of taxonomic versus ecological categorization of prey. Stud. Avian Biol., 13: 104-109.

de Juana, E., J.M. Bueno, M. Carbonell, V. Perez-Mellado and J. Varela. - 1979. Aspectos de la alimentación y biología de reproducción de Larus audouinii Payr. en su gran colonia de cria de las islas Chafarinas (año 1976). Bol. Est. Central Ecología, 16: 53-66.

Demestre, M., J. Lleonart, P. Martín, L. Recasens and P. Sánchez 1988. La pesca en Cataluña. FAO Rapport sur les Pêches, 395 : 101-103.

Díaz, J.A. and M. Díaz. - 1990. Estimas de tamaños y biomasas de artrópodos aplicables al estudio de la alimentación de vertebrados insectívoros. Doñana, Acta Vertebrata, 17: 67-74.

Estrada, M. - 1996. Primary production in the northwestern Mediterranean. In: I. Palomera and P. Rubiés (eds.), The European anchovy and its Environment. Sci. Mar. 60(Supl. 2): 55-64.

Font, J., C. Millot, J. Salas, A. Julia and O. Chic. - 1998. The drift of modified Atlantic water from the Alboran Sea to the eastern Mediterranean. Sci. Mar., 62: 211-216.

Fox, G.A., L.J. Allan, D.V. Weseloh and P. Mineau. - 1990. The diet of herring gulls during the nesting period in Canadian waters of the Great Lakes. Can. J. Zool., 68: 1075-1085.

Furness, R.W., K. Ensor and A.V. Hudson. - 1992. The use of fishery waste by gull populations around the British Isles. Ardea, 80: 105-113. 
GFCM. - 1967. Fisheries resources review of the Mediterranean and Black sea. FAO Fish. Rep., 9: 67 pp.

- 1991. Nominal catches 1977-1989. FAO Stat. Bull., 8: 31-211.

González-Solís, J., D. Oro, V. Pedrocchi, L. Jover and X. Ruiz. 1997a. Trophic niche width and overlap of two sympatric gulls in the southwestern Mediterranean. Oecologia, 112: 75-80.

González-Solís, J., D. Oro, V. Pedrocchi, L. Jover and X. Ruiz. 1997b. Bias associated with samples in gulls. Condor, 99: 773-779.

González-Solís, J., X. Ruiz and L. Jover. - 1998. Fisheries and daily activity cycles of Audouin's Larus audouinii and Yellowlegged Gulls L. cachinnans breeding at the Chafarinas Islands (Moroccan coast). Vogelwarte, 40: 52-56.

Hillström, L., M. Kilpi and K. Lindström. - 1994. Diet of Herring Gulls Larus argentatus during chick rearing in the Gulf of Finland. Orn. Fennica, 71: 95-101.

Hutcheson, K. - 1970. A test for comparing diversities based on the Shannon formula. J. Theor. Biol., 29: 151-154.

Irazola, M., A. Lucchetti, J. Lleonart, A. Ocaña, J.M. Tàpia and S. Tudela. - 1996. La pesca en el siglo XXI: Propuestas para una gestión pesquera racional en Catalunya. CCOO, CEPROM, FORCEM. 289 pp.

Mester, H. - 1971. Die Vogelwelt der Pityusen. Bonn. Zool. Beitr., 22: $28-89$.

Mudge, G.P. and P.N. Ferns - 1982. The feeding ecology of five species of gulls (Aves: Larini) in the inner Bristol Channel. $J$. Zool., London, 197: 497-510.

Oro, D. - 1995. The influence of commercial fisheries in daily activity of Audouin's Gull (Larus audouinii) in the Ebro Delta, NE Spain. Orn. Fennica, 72: 154-158.

Oro, D. - 1998. Audouin's gull account. In: The Birds of Western Paleartic, pp. 47-61. Ed. by M. A. Ogilvie. Oxford University Press, Oxford.

Oro, D. - 1999. Trawler discards: a threat or a resource for opportunistic seabirds? In: Proceedings XXII International Ornithological Congress, Durban, pp. 717-730. Ed. by N.J. Adams and R.H. Slotow. Johannesburg, BirdLife South Africa.

Oro, D., L. Jover and X. Ruiz. - 1996a. Influence of trawling activity on the breeding ecology of a threatened seabird, Audouin's Gull Larus audouinii. Mar. Ecol. Progr. Ser., 139: 19-29.

Oro, D., X. Genovart, X. Ruiz, J. Jiménez and J. Garcia-Gans. 1996b. Differences in diet, population increase and breeding performance between two colonies of Audouin's Gulls Larus audouinii during breeding seasons affected by a trawling moratorium. J. Avian Biol., 27: 245-251.

Oro, D. and X. Ruiz. - 1997. Seabirds and trawler fisheries in the northwestern Mediterranean: differences between the Ebro Delta and the Balearic Is. areas. ICES J. Mar. Sci., 54: 695-707.

Oro, D., X. Ruiz, L. Jover, V. Pedrocchi and J. Gonzalez-Solis. 1997. Audouin's Gull diet and adult time budget responses on changes in food availability induced by commercial fisheries. Ibis, 139: 631-637.

Oro, D. and G.D. Ruxton. - 2001. The formation and growth of seabird colonies: Audouin's gull as a case study. J. Anim. Ecol., 70: $527-535$.

Palomera, I. - 1992. Spawning of anchovy Engraulis encrasicholus in the Northwestern Mediterranean relative to hydrographic features in the region. Mar. Ecol. Progr. Ser., 79: 215-223.

Palomera, I. and J.P. Pertierra. - 1993. Anchovy biomass estimate by the daily egg production method in 1990 in the Western Mediterranean Sea. Sci. Mar., 57: 243-251.

Pedrocchi, V., D. Oro and J. González-Solís. - 1996. Differences between diet of adults and chicks Audouin's Gull Larus audouinii at the Chafarinas Islands, SW Mediterranean. Orn. Fennica, 73: 124-130.

Pielou, E.C. - 1975. Ecological diversity. John Wiley \& Sons, New York.

Ricklefs, R.E., D.C. Hahn and W.A. Montevecchi. - 1978. The relationship between egg size and chick size in the Laughing Gull and Japanese Quail. Auk, 95: 135-144.

Rogers, L.R., R.L. Buschbom and C.R. Watson. - 1977. Lengthweight relationships of shrub-Steppe invertebrates. Ann. Ent. Soc. Am. 70: 51-53.

Rubin, J.P. -1997. Special Publications of the Spanish Institute of Oceanography; The effect of physicochemical and biological processes on the composition and distribution of the summer ichthyoplankton of the Alboran Sea and the Strait of Gibraltar. In: J.P. Rubin (ed.) La influencia de los procesos fisicoquimicos y biologicos en la composicion y distribucion del ictioplancton estival en el mar de Alboran y estrecho de Gibraltar. Publ. Esp. Inst. Esp. Oceanogr., 24. 87p.

Ruiz, X., D. Oro., A. Martínez and L. Jover. - 1996. Feeding ecology of Audouin's Gull Larus audouinii in the Ebro Delta. pp 68-74. In Ecology, conservation and management of colonial waterbirds in the Mediterranean region. A.J. Crivelli, H. Hafner, M. Fasola, R.M. Erwin and D.A. McCrimmon Jr. (eds.) Col. Waterbirds, 19, Spec. Publ. 1.

Ruiz, X., J. González-Solís, D. Oro and L. Jover. - 1998. Body size variation in Audouin's Gulls Larus audouinii: a density-dependent effect? Ibis, 140: 431-438.

Salat, J. - 1996. Review of hydrographic environmental factors that may influence anchovy habitats in northwestern Mediterranean. In: I. Palomera and P. Rubiés (eds.) The European anchovy and its Environment, pp. 21-32. Sci. Mar. 60, Supl. 2.

Spaans, A.L. - 1971. On the feeding ecology of the Herring Gull Larus argentatus Pont. in the Northern part of the Netherlands. Ardea, 59: 73-188.

Wallace, D.I.M. - 1969. Observations on Audouin's gulls in Majorca. British Birds, 62: 223-229.

Witt, H-H. - 1977a. Zur Verhaltensbiologie der Korallenmöwe Larus audoinii. Zeits. Tierps., 43: 46-47.

Witt, H-H. - 1977b. Zur biologie der Korallenmöwe Larus audouinii- Brut und Ernährung. J. Orn., 118: 134-155.

Witt, H-H., J. Crespo, E. de Juana and J. Varela - 1981. Comparative feeding ecology of Audouin's Gull Larus audouinii and the Herring Gull L. argentatus in the Mediterranean. Ibis, 123: 519526.

Zahl, S. - 1977. Jackknifing - an index of diversity. Ecology, 58: 907-913.

Zar, J.H. - 1984. Biostatistical Analysis. Prentice-Hall Ed., London.

Scient. ed.: P. Abelló 